12,1957 , north of Calgary; Mrs. Scoular one bird March 17, 1957 five miles south of Red Deer.

ERSKINE, ALTA.-Lloyd M. Lohr has records dating from 1954, as follows: March 2, 1954 (2), March 22 (12). June 12 (young first seen), June 16 (large flock at barn); March 27, 1955 (first arrival date), March 19, 1956 (first arrival), May 13 (young heard in old woodpecker hole), June 5 (young flying); March 2, 1957 (first arrival). These records show that Starlings do not winte the locality. "They move in du March and feed around the build mostly on offal from butcherin kitchen scraps, or suet at the fee tray. By April's end they are ne in the surrounding poplar grove old woodpecker holes. The younc very noisy and are easily loc: June finds the young flying, an July they flock up and are along roadsides and are gone by ust."

SPECIMEN RECORDS: Department of Bislogy, University of Sask., Saskatoon. No. 384. 1947. \& Scott, Sask. coll. by F. Rouse; No. 389. Nov. 28, 1947. \& Fairy Hill, Sask by Mrs. C A Stewart: No 390 April 5, 1949. J Lake Lenore, Sask. coll. by R. N, lems; No. 392. March 17, 1950. đ Hodgeville, Sask. coll. by M. Atherton.

\title{
The New York State Standards of Abundanc Frequency and Occurrence
}

( A committee frcm the Federation of New York State Birf Clubs has, after much conside: and stcidv, formulated a set of standards so that bird abundance and occurance can be unif reported. It is hoped that these will be adopted across the continent. They have given mission to reproduce these in the BLUE JAY-C.S.H.)

\section{ABUNDANCE SCALE, NON-BREEDING}

Abundant: Occurring in such numbers that a competent observer at the propriate time and place might see or hear more than 500 individuals single day.

Very common: 101-500 in a single day.

Common: $26-100$ in a single day.

Fairly common: $6-25$ in a single day.

Uncommon: $1-5$ in a single day (no more than 25 per season).

Rare: $1-5$ in a single day (no more than 5 per season).

Very rare: No more than 1 per day (and 1 per season).

\section{ABUNDANCE SCALE, BREEDING}
Breeding density
(flicker size or smaller)
1 pair per 26-125 acres.
1 pair per 125-640 acres
1 pair per 6-25 sq. miles.
1 pair per 26 or more sq. miles.
Breeding density (larger than flicker)
1 pair per 1-25 acres.
1 pair per 26-125 acres.
1 pair per .125-640 acres.
1 pair per $1-5$ sq. miles.
1 pair per 6-25 sq. miles.
1 pair per 26-125 sq. miles.
1 pair per 126 or more sq.

ABUNDANT

VERY COMMON COMMON

FAIRLY COMMON

UNCOMMON

RARE

VERY RARE

1 pair per 1-5 acres.

1 pair per $6-25$ acres.

1 pair per 1-5 sq. miles.

\section{FREQUENCY STANDARD}

Regular: Recorded every year.

Irregular: Recorded less than once every year, but no less than once in years, on the average.

Occasional: Recorded less than once in five years, but no less than onc ten years on the average.

Sporadic: Recorded less than once in ten years, but no less than onc twenty years, on the average.

Casual: Reccrded less than once in twenty years, on the average.

Exotic (or Accidental): Recorded but, because of its normal range, not $x$. pected to occur again.

\section{SEASONAL OCURRENCE}

Residents: Breeding species; may occur as summer residents or perma $n$ residents.

Transients: Birds of passage which occur in spring and/or fall but do breed; may occur as spring transients or fall transients.

Visitants: Non-breedings birds which occur as temporary visitors; may as summer visitants, winter visitants or vagrant visitants (irregular season). 